\title{
Investigation of The Analgesic and Anti-Inflammatory Activities of Launaea Nudicaulis From Southwest of Algeria
}

\author{
Lamia Salima Seddiki ${ }^{1}$, Nasser Belboukhari*1, Aminata ould el hadj khelil ${ }^{4}$, Mohd Roslan Sulaiman ${ }^{3}$, \\ Mimouna Yakoubi ${ }^{1}$, Khaled Sekkoum ${ }^{1}$ and Abdelkarim Cheriti $^{2}$ \\ ${ }^{1}$ Bioactive Molecules \& Chiral Separation Laboratory, Algeria \\ ${ }^{2}$ Phytochemistry and organic synthesis laboratory, Algeria \\ ${ }^{3}$ Inflammatory and Pain Group, Faculty of Bioscience and Health, Malaysia \\ ${ }^{4}$ Faculty of Science of Nature and Life, Algeria \\ *Corresponding author: Nasser Belboukhari, Bioactive Molecules \& Chiral Separation Laboratory. Fac exact sciences, University \\ Tahri Mohamed, Bechar 08000, Algeria
}

\section{ARTICLE INFO}

Received: 㓞 November 13, 2019

Published: 慧 November 21, 2019

Citation: Lamia Salima Seddiki, Nasser Belboukhari, Aminata ould el hadj khelil, Mohd Roslan Sulaiman, Mimouna Yakoubi, Khaled Sekkoum, Abdelkarim Cheriti. Investigation of The Analgesic and Anti-Inflammatory Activities of Launaea Nudicaulis From Southwest of Algeria. Biomed J Sci \& Tech Res 23(1)-2019. BJSTR. MS.ID.003858.

\begin{abstract}
Inflammations and pain have always been the cause of serious health problems; to treat these problems, the population in south west of Algeria use medicinal plants as an alternative way. Within the same framework, the aim of this study is to explore the potential of aqueous extract of Launaea nudicaulis for their anti-inflammatory and analgesic activities. The anti-inflammatory and analgesic activities were evaluated using an acetic acid test-induced abdominal writhing and formalin test-induced paw edema. To assess the mechanism of anti-inflammatory action, the extract was tested against different phlogistic agents such as histamine and serotonin in addition to a test about the effect of the extract on capsacinoid receptors. The result of this work showed the aqueous extract of L.nudicaulis inhibits $99 \%(\mathrm{P}<0.0001)$ of the abdominal writhing and reduces the volume of the hide paw edema by $70 \%,(\mathrm{P}<0.0001)$.The aqueous extract reduces hide paw edema induced by histamine and serotonin; moreover the extract was effective on capsacinoid receptors by an inhibition rate that reached $50 \%$. The physicochemical analysis of the extract showed presence of potent analgesic and antiinflammatory compounds as Thymol, trans-Totarol, Eugenol and other compounds.
\end{abstract}

Keywords: Launaea nudicaulis; Inflammation; Algesic; Histamine; Serotonin; Capsacine

\section{Introduction}

Launaea nudicaulis is widely present in the south-western region of Algeria especially during the spring season. Launaea nudicaulis is an herb which belongs to Asteraceaes family. It widely grows in arid and semiarid region. It is known as rehgama in in the southwest of Algeria. It is a perennial herb with a taproot and often shoot bearing lateral roots, up to $40-50 \mathrm{~cm}$ high at anthesis. Caudical leaves, rather variable, narrowly spathulate in outline, sinuatedentate to irregularly pinnatifid to mostly runcinate, Flowers with a bright yellow ligule [1] (Figure 1). Many of the plants belonging to the Launaea genus are used in traditional medicine for skin disease, as anti-tumors, antihelmintics, insecticidal and for renal disorders $[2,3]$. The genus Launaea possesses phytochemical features, such as terpenoids, phenolics, flavones and coumarins [4,5]. Many of those secondary metabolites were reported to have an antiinflammatory and analgesic activities, tritepenoids, flavonoids, coumarins. Different phytochemical studies showed the benefits of triterpanoids and flavonoids against tumors, oxidative stress [6,7] nudicaulin A, nudicaulin B, and nudicaulin $C$ in addition to its ability to inhibit lipoxygenase [8]. Arthriterhumatoids, ulcer, eczma, and other inflammation illness, are still treated by physiotherapeutic 
methods including Launaea nudicaulis, which is used to treat those ailments by the inhabitants of southwest Algeria. Inflammation is usually associated with pain. The aim of this present study is to confirm the efficiency of the traditional use of the plant in the case of inflammatory diseases. The present work explores the antiinflammatory and anti-nociceptive activities of Launaea nudicaulis in rodents' animal.

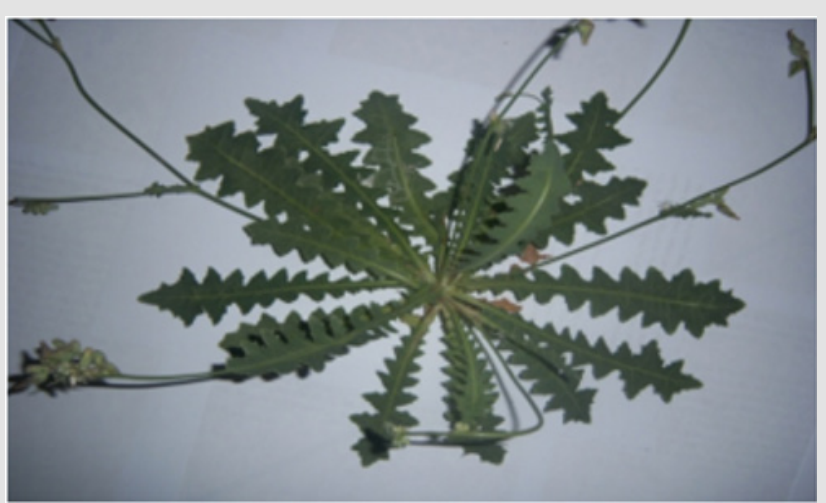

Figure 1: Launaea nudicaulis.

\section{Material and Methods}

\section{Plant Materials}

The aerial parts of the plant were collected from the suburbs of Bechar in spring.The aerial part was dried and powdered. The powdered plant $(50 \mathrm{~g})$ was extracted using $300 \mathrm{ml}$ distilled water which was refluxed for 2 hours. The aqueous extract of Launaea arborescens (AqELN) was filtered and dried to obtain a crude dried extract. The extract was prepared in 3 doses 30,100, $300 \mathrm{mg} / \mathrm{kg}$ for anti-inflammatory and anti-nociceptive assay, the rest of AqELN was stored at $4^{\circ} \mathrm{C}$. To prepare the aqueous solution, the dryed extract of aqueous of L.A (AqELN) was diluted in vehicle were made up of $5 \%$ ethanol, $5 \%$ tween 20 , and $90 \%$ distilled water for antiinflammatory and anti-nociceptive studies

\section{Animals}

Male of BalB/c mice (20-25g) were procured from Pasteur Institute (Algiers). All animals were housed in polypropolylene cages in temperature-controlled room at $25{ }^{\circ} \mathrm{C}$ (standard conditions) and with access to food and water ad libitum.

\section{Reagents and Chemicals}

The following drugs and chemicals were used: morphine hydrochlorid, formaldehyde, acetic acid, ethanol, morphine, and diclofenac (Frater Razers), serotonin, histamine, capsacine, capsazepine, ASA, loratadine, and mianserine (from sigma aldrish).

\section{Acetic Acid Test}

Acetic acid test was described by Koster et al. [9]. Mice were grouped into 6 groups each comprising 6 mice, they were treated by intraperitoneal with AqELN at different doses: 30, 100, $300 \mathrm{mg} /$ $\mathrm{kg}$, diclofenac $(100 \mathrm{mg} / \mathrm{kg})$ or vehicle $(10 \mathrm{ml} / \mathrm{kg})$ Each mouse was injected with $0.8 \%$ of aqueous solution, acetic acid $(10 \mathrm{ml} / \mathrm{kg})$, and intraperitoneal (i.p) 30 minutes after the treatment. The mice were placed in a separated individual chamber. The abdominal writhing was counted after $5 \mathrm{~min}$ following acetic acid injection. The number of writhing inducements was recorded for the treated mice and compared to that of untreated ones.

The inhibition was calculated by the following formula:

((negative mean- treated mean) /negative mean) x 100

\section{Formalin Test}

The formalin test was described by first Dubuisson and Dennis (1977) [10] using the formalin-induced mouse paw edema test. Thirty minutes after injection of AqELN (30, 100, $300 \mathrm{mg} /$ $\mathrm{kg}$ ) or diclofenac $(100 \mathrm{mg} / \mathrm{kg})$ or vehicle $(10 \mathrm{ml} / \mathrm{kg}), 20 \mu \mathrm{l}$ of formaldehyde solution ( $2.5 \%$ concentration: $\mathrm{v} / \mathrm{v}$ in distilled water) was injected intra-planta of right hind paw. The time spent licking or biting the injected paw was measured [11]. The duration of nociceptive behavioral responses to including biting and licking of the injected paw were observed and reached $30 \mathrm{~min}$. The first $5 \mathrm{~min}$ is the first phase (neurogenic phase) followed by quiescent interval of $10 \mathrm{~min}$, and the subsequent second phase of activity lasted up to 15 min. Tests were carried out in triplicate samples concentration providing $50 \%$ inhibition. IC50 was obtained by plotting the inhibition percentage against sample concentration.

\section{Histamine and Serotonin Test}

Histamine and serotonin-induced mice paw edema induce vascular permeability. The mice were treated with aqueous extract of L.nudicaulis (AqLN) using three doses $(30,100,300 \mathrm{mg} / \mathrm{kg}$ ) by intraperitoneal injection. After 30 minute the mice underwent subplantar injection of histamine or serotonin $(10 \mu \mathrm{l} / 1 \mathrm{ml})$. Loratadine and mianserine are positive control elements [12]. The edema paw was assessed every $30 \mathrm{~min}$ during $150 \mathrm{~min}$ to $180 \mathrm{~min}$.

$$
\% \text { inhibition }=[V c-(V t / V c)] \times 100
$$

Where Vc represents the mean edema in the control group and Vt represents the mean edema in the group treated with vehicle or extract.

\section{Capsaicine Test}

The mice were treated with aqueous extract of L. nudicaulis (AqLN) using three doses (30, 100, $300 \mathrm{mg} / \mathrm{kg}$ ) by means of intraperitoneal injections. After 30 minutes the mice had a subplantar injection of capsacin $(10 \mu \mathrm{l} / 1 \mathrm{ml})$; capsazepine $(0.17$ $\mathrm{mmol} / \mathrm{kg})$, dicofenac $(10 \mathrm{mg} / \mathrm{kg})$ and ASA (100 mg/kg) are positive control substances injected in an intraperitoneal way [13].

\section{Essential Oil Analysis}

A GC analysis was carried out using a SHIMADZU GC-2014 gas chromatograph equipped with a FID and two capillary 
columns; DB-5 (non-polar) and Carbowax 20M (polar) column $(30 \mathrm{~m} \times 0.32 \mathrm{~mm} ; 0.25 \mu \mathrm{m}$ film thickness). The carrier gas was N2. Analytical conditions were as follows: injector and detector temperatures, $220^{\circ} \mathrm{C}$ and $240^{\circ} \mathrm{C}$ respectively. Oven temperature programmed from 50 to $210^{\circ} \mathrm{C}$ at $3 \% \mathrm{~min}$, and finally held to $240^{\circ} \mathrm{C}$ at $10^{\circ} / \mathrm{min}$. the injected volume was $1 \mu \mathrm{l}$, using split injection, with a ratio of 1.0. The oil components were identified from their GC retention indices, by comparison with those reported in the literature. The linear retention indices were determined in relation to a homologous series of n-alkanes $\left(\mathrm{C}_{6}-\mathrm{C}_{44}\right)$ under the same operating conditions (programmed temperature) in two capillary columns (DB-5 and Carbowax 20M).

\section{Statistical Analysis}

Statistical analysis was carried out using the one-way ANOVA and was followed by Turkey and Dunnet's post-test and Bonferoni post-test. The results were expressed as mean \pm SEM

\section{Results and Discussion}

Pain and inflammation are two inseparable indicators of body discomfort, apart from their pathological signification. The present study on the evaluation of the anti-inflammatory and analgesic activity of the aqueous extract of L.N showed a potential of effectiveness using different tests. The result of acetic acid test showed a significant inhibition $(\mathrm{P}<0.0001)$ that started with low dose $30 \mathrm{mg} / \mathrm{Kg} 70 \%$ of inhibition of abdominal writhing (EC50 = 171). The percentage of inhibition using diclofenac and morphine were $78 \%$ and $99 \%$ respectively (Figure 2). In acetic acid-induced abdominal writhing which is visceral pain and inflammation, the process released several pain and inflammatory mediators mainly prostaglandine and lipoxegenase. The aqueous extract showed a significant inhibition of abdominal writhing, it is possible that the flavonoids compound has a negative effect on prostaglandins and / or lipoxegénase metabolism pathway [14], compared to diclofenac and morphine as positive control. The Aqueous LN treatment exhibited maximum inhibition of $66 \%$ in Formalin-induced mouse paw edema in the neurogenic phase at a dose of $100 \mathrm{mg} /$ $\mathrm{kg}$, whereas diclofenac and morphine produced $78 \%$ and $89 \%$ of inhibition respectively (Figure 3).

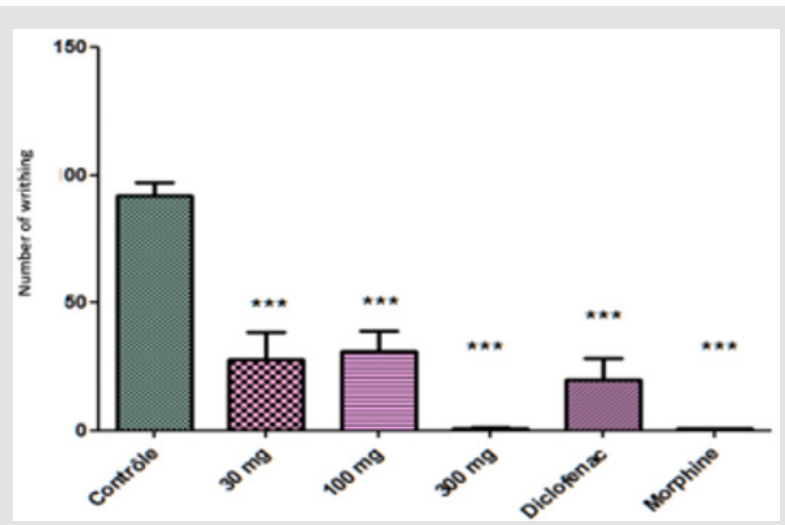

Figure 2: Effect of Launaea nudicaulis (AqLN) mouse abdominal writhing; $\mathrm{p}<0.0001$ compared to the control.
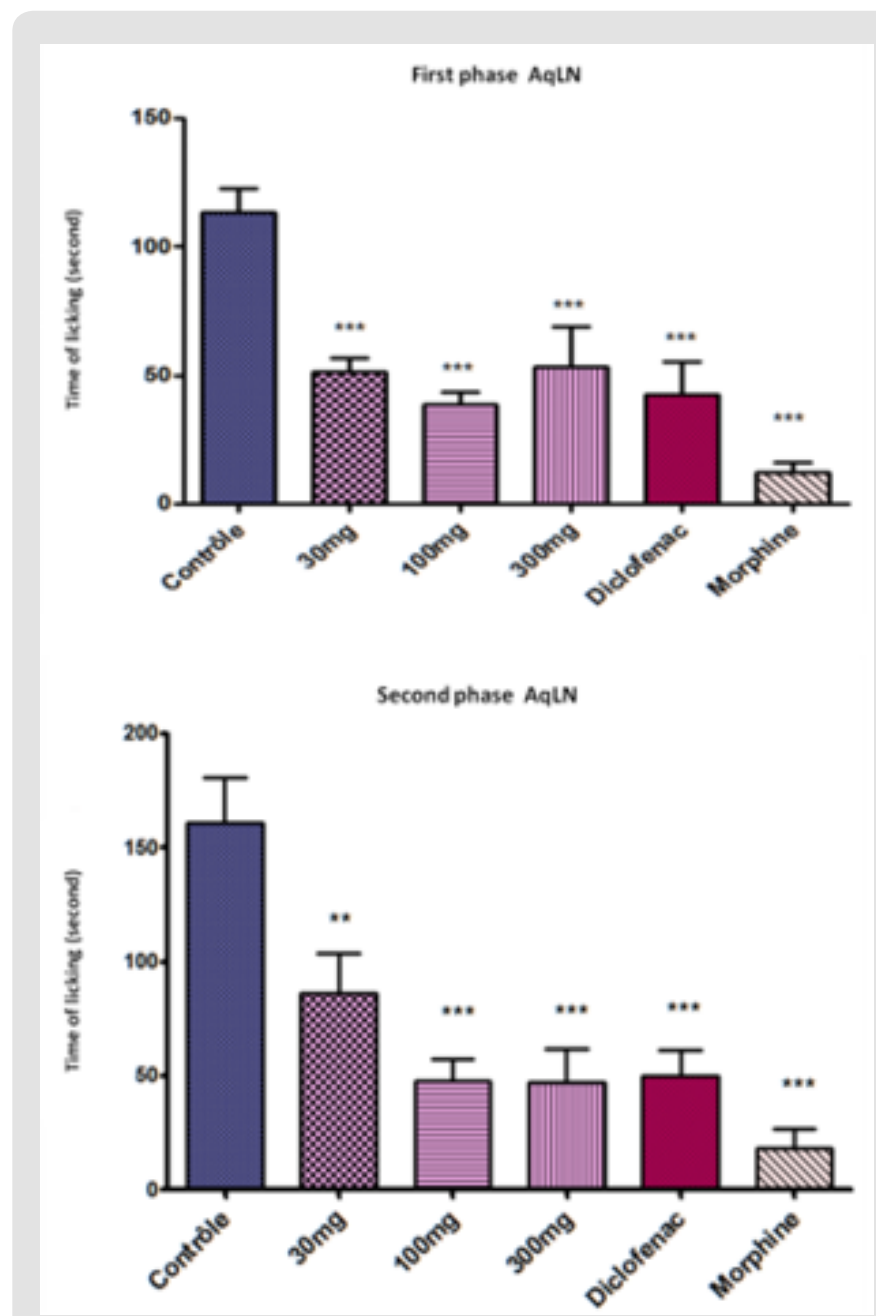

Figure 3: Effect of Launaea nudicaulis (AqLN) in formalin test; first phase, and second phase. $p<0.0001$ compared to the control.

In the second phase of formalin test, the licking paw inhibition is $70 \%$ for $100 \mathrm{mg} / \mathrm{Kg}$ (EC50 $=78.75 \mathrm{mg} / \mathrm{kg}$ ), and whereas is $69 \%$ and $89 \%$ for diclofenac and morphine respectively. It was a significant inhibition $(\mathrm{P}<0.0001)$ for both phases (Figure 3). The formalin test is characterized by two phases, neurogenic and inflammatory phase. In the first phase the effect of the aqueous extract was significant starting with the lowest doses. The formalin induced a neurogenic inflammation in the first 5 minutes. At this moment, the peripheral axon terminals of sensory nerves released neuropeptides that produce a vasodilatation, edema, and other manifestations of inflammation [15]. The extract of Launaea nudicaulis exhibited a significant effect against the neurogenic inflammation; the aqueous extract may exert an inhibition of neurogenic peptides release. However, in the second phase the formalin stimulated the other inflammation compounds. The treated groups showed an inhibition of licking of the injected paw that suggest the aqueous extract of Launaea nudicaulis may decrease the effect of pro-inflammatory mediators.

Diclofenac is non-steroidal anti-inflammatory drug (NSAIDS), inhibitor of cyclooxygenase (COX 1 and COX 2), where morphine 
is an opioid, antagonist of $\mu$ receptor on fiber A. Diclofenac and morphine reduce the nociceptive behaviour during the first and second phase. According to Shibata et al. (1998) [16] morphine inhibits both phases acting centrally and peripherally [16]. The aqueous extract AqLN elicited significant inhibition $(\mathrm{P}<0.001)$ of $51 \%$ with a dose of $300 \mathrm{mg} / \mathrm{kg}$ in capsaicin-induced mouse paw edema, while diclofenac and capsazepine exhibited $60.04 \%$ and $60.43 \%$ of inhibition respectively (Figure 4 ). The injection of capsacin hind paw exerts a pain related to the behaviours as biting and licking. The capsaicin excites vanilloid-sensitive neurons; they are peptidergic, small diameter $(50 \mu \mathrm{m})$ neurons, giving rise to thin, unmyelinated C fibers $[17,18]$. The capsaicin effects are mainly associated with stimulus of unmyelinated and poorly myelinated $\mathrm{A} \delta$ primary sensory afferent fibres, termed C-polymodal nociceptors, which are abundant in nociceptive neurons [15].

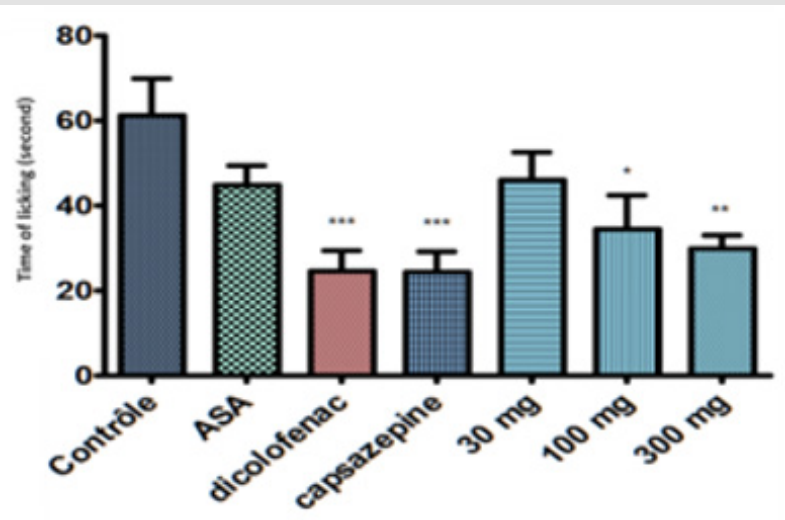

Figure 4: Effect of Launaea nudicaulis (AqLN) capsacinoid receptors. $\mathrm{p}<0.001$ compared to the control.

Using the capaszepin is selectively antagonizing responses mediated by capsaicin. The aqueous extract result showed a significant effect against irritation and edema induced by capsaicin injection, specifically at the high dose $(300 \mathrm{mg} / \mathrm{kg})$. On the light of this observation, it may be deduced that the extract inhibits capsanoid receptors effect (Figure 4). Diclofenac and NSAID reduced the effect of capsaicin in same percentage of inhibition but maybe not the same way as capsazipin. Using the aqueous extract of L. nudicaulis in serotonin and histamine induced mouse edema paw showed decrease in the volume of the edema as a function of time (Figures $5 \& 6$ ). The effective dose of the extract is dose-dependent for the serotonin test is $30 \mathrm{mg} / \mathrm{kg}$, and the $\mathrm{EC}_{50}=125.1 \mathrm{mg} / \mathrm{kg}$; the result is not significant (Figure 6). The effective experimental dose is $300 \mathrm{mg} / \mathrm{kg}$ for histamine test $\mathrm{EC}_{50}=116.6 \mathrm{mg} / \mathrm{kg}$, the result is significant $(\mathrm{P}<0.0001)$ at $150 \mathrm{~min}$ (Figure 5). The serotonin and histamine are peptide released by the mastocyte in inflammation process; both can increase inflammation and the nociception process. In the periphery, the histamine is mainly synthesized and released by basophils, mast cells and enterochromaffine; it causes pruritus and increase in vascular permeability, resulting in erythema and edema; symptoms associated with immediate-type (type I) allergies [19].

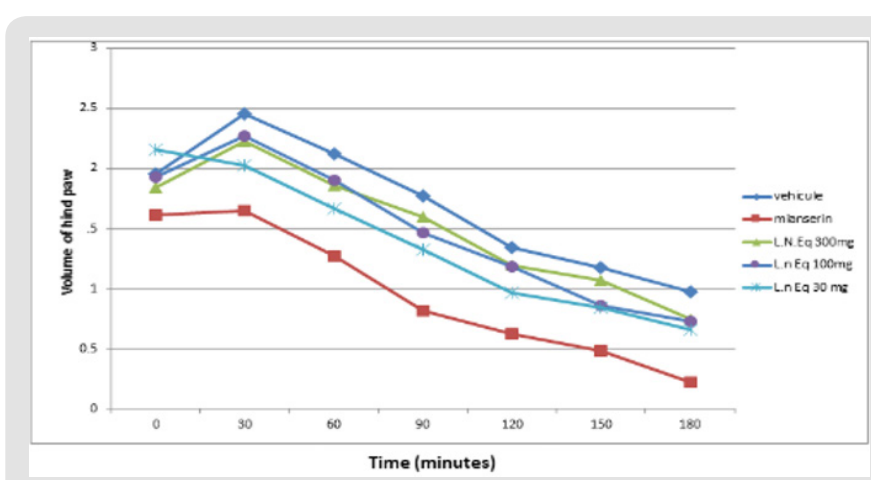

Figure 5: Effect of Launaea nudicaulis (AqLN) on serotonin induced paw edema. $\mathrm{P} \geq 0.05$ compared to the control.

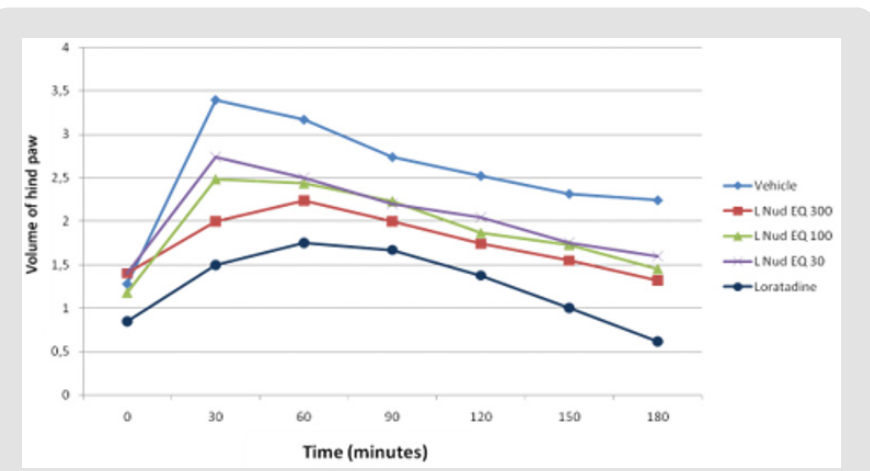

Figure 6: Effect of Launaea nudicaulis (AqLN) on histamine induced paw edema. $p<0.0001$ compared to the control.

Loratadine is an anti-histaminergic; it is a peripheral $\mathrm{H} 1$ receptors antagonist and does not cross the blood-brain barrier. This drug is effective in inhibiting vascular permeability, edema formation, broncho constriction, and pruritus associated with histamine release. It neither prevents histamine release nor reduces the amount released [20]. On this view, the aqueous extract of L.N decreases the effect of histamine vascular permeability and edema as a function of time. The serotonin tissue content increases rapidly in inflammation or injury. The main cellular sources of serotonin in peripheral tissues are platelets and mast cells. After release of serotonin, its action depends on the receptors present on afferent nerves in the vicinity $[21,22]$. In peripheral tissues, serotonin acts as a proalgesic inflammatory mediator [23] Mianserin is a quadricyclic compound with complex pharmacological actions. It has weak noradrenaline reuptake inhibiting effects and is a fairly potent antagonist at a number of neurotransmitter receptors, including 5-HT2, 5-HT3, noradrenergic $\alpha 1$ - and $\alpha 2$-adrenoceptors [24]. The extract of L.N decreased the volume of edema and vasodilatation of hind paw of mice induced by serotonin at dose-depend, whereas effective response was at $150 \mathrm{~min}$.

\section{GC-MS of Launaea Nudicaulis' Essential Oil}

The results of CG-MS show a variety of compounds that constitute the essential oil of Launaea nudicaulis (Table 1), they were mostly of the terpanoids class as Neo-Phytadieneisomere, Trans-Ocimenol, $\beta$-Bisabolene, Thymol, Cadinol-T, Bornylacetate, 
$\alpha$-Terpinene, and were capable of inhibiting the expressions of the tumor necrosis factor (TNF-alpha), IL-6, IL-1, pro IL-1beta, NO, iNOS, and NLRP3 in murine macrophage cells [25]. This study was confirmed by Gholijani et al. [26] where demonstrated the thymol can modulate inflammatory process.

Table1: Composition of essential oil of Launaea nudicaulis (RI= Retention indices; $a=$ comparison of our MS data with literature data; $b=$ comparison of our RI data with literature data).

\begin{tabular}{|c|c|c|c|}
\hline & Composition & RI(DB-5) & RI(CW20M) \\
\hline 1 & Methylbutanal & 646 & - \\
\hline 2 & Cis-1,3 Dimethylcyclopentane & 688 & 676 \\
\hline 3 & Pentanal & 720 & 1131 \\
\hline 4 & 3-Methyl-1-heptanene & 753 & - \\
\hline 5 & 2-Methyl-1-heptanene & 787 & - \\
\hline 6 & Hexanal & 826 & - \\
\hline 7 & 3-Methyl-1-octene & 843 & - \\
\hline 8 & $\alpha$-Terpinene & 1017 & 1182 \\
\hline 9 & Trans-Allo- Ocimene & - & 1391 \\
\hline 10 & Bornylacetate & - & 1565 \\
\hline 11 & Humulane & - & 1609 \\
\hline 12 & Verbinone & 1205 & 1731 \\
\hline 13 & Geraniol & 1255 & 1797 \\
\hline 14 & $\beta$-Vetvenene & - & 1885 \\
\hline 15 & Geranylisopentanoate & - & 1895 \\
\hline 16 & $\alpha$-Calacorene & - & 1917 \\
\hline 17 & $\beta$-Ionone & - & 1924 \\
\hline 18 & Neo-Phytadieneisomere & - & 1956 \\
\hline 19 & Trans-Cinnamaldehyde & 1266 & 2096 \\
\hline 20 & Eugenol & 1356 & 2085 \\
\hline 21 & Nerylpropionate & 1454 & 1771 \\
\hline 22 & Trans-Ocimenol & 1508 & 1685 \\
\hline 23 & $\beta$-Bisabolene & 1509 & 1744 \\
\hline 24 & Chamazulene & 1522 & 1520 \\
\hline 25 & Cis-Nerolidol & 1534 & 1960 \\
\hline 26 & - & - & 1991 \\
\hline 27 & Thymol ouBisaboloxide & 1744 & 2116 \\
\hline 28 & Caryophylla4(14),8(15)-dien-5 $\beta$-ol & - & 2372 \\
\hline 29 & Eicosane & 2000 & 2000 \\
\hline 30 & 2-Methyl-1-Eicosane & 2090 & - \\
\hline 31 & Octadecadienoicacid & 2095 & - \\
\hline 32 & $\begin{array}{c}\text { Octadecylacetate } \\
\text { ouMethyloctadecanoate }\end{array}$ & 2129 & - \\
\hline 33 & Cadinol-T & 2135 & - \\
\hline 34 & Incensole & 2150 & - \\
\hline 35 & Docosane & 2200 & 2200 \\
\hline 36 & Trans-Totarol & 2234 & - \\
\hline 37 & Dehydroabietol & 2382 & - \\
\hline 38 & Tetracosane & 2400 & 2400 \\
\hline 39 & Hexacosane & 2600 & 2600 \\
\hline
\end{tabular}

\section{Conclusion}

Pharmaco-copia are mostly used in southwest Algeria (Saoura region), with water as the main solvent for their preparation. Based on the results obtained from the study it can be concluded that L.nudicaulis possesses significant anti-inflammatory potential in vivo and is also effective in inflammation associated with pain in mice. The present study indicates that aqueous extracts of L.nudicaulis have significant effects on peripheral and central pain. The anti-inflammatory mechanism of L. nudicaulis is related to inhibition of prostagladine synthase or /and cyclogenase (Cox) and the release of serotonin and histamine may desactivate capcinoid receptors.

\section{References}

1. https://www.gbif.org/species/3144742 visited 21/10/2018

2. Saleh MRI, Habib AAM, El Ghazooly MG, Gabr OMK, El Fiky FK, et al. (1988) Chemical constituents of Launaea nudicaulis (L.) Egypt. J Pharm Sci 29: 507-513.

3. Sarg TM, Omar AA, Khafagy SM, Grenz M, Bohlman F, et al. (1982) Naturally occurring terpene derivatives. Phytochemistry 21: 1163.

4. Abdelkrim Cheriti, Mebarka Belboukhar, Nasser Belboukhari, Houria Djeradi (2012) Phytochemical and biological studies on Launaea Cass. genus (Asteraceae) from Algerian Sahara. Current Topic in Phytochemistry 11

5. Sarg TM, Omar AA, Ateya AM, Hafiz SS (1986) Phenolic constituents of Launaea nudicaulis (L.) Egypt. J Pharm Sci 25: 35-40.

6. Sahreen S, Khan M R, Khan R A (2011) Hepatoprotective effects of methanol extracts of Carissa opaca leaves on CCl4 induced damage in rat. BMC Compl Alter Med 24: 11-48.

7. Marles R, Farnsworth N (1994) Plants as sources of antidiabetic agents. In: Wagner, $\mathrm{H}$ Farnsworth, NR (Edn.) Economic and Medicinal Plant Research, Academic Press Ltd. UK 6: 149-187.

8. Riaza N, Parveena S, Saleema M, Shaiq Alib M, Malik A, et al. (2012) Lipoxygenase inhibitory sphingolipids from Launaea nudicaulis. Journal of Asian Natural Products Research 14(6): 545-554.

9. Koster R, Anderson M, De Beer EJ (1959) Acetic acid for analgesic screening. In: Federation Proceedings 18: 412-418.

10. Dubuisson D, Dennis SG (1977) The formalin test: A quantitative study of the analgesic effects of morphine, meperidine, and brain stem stimulation in rats and cats. Pain 4(2): 161-174.

11. Hunskaar S, Fasmer OB, Kjell H (1985) Formalin test in mice, a useful technique for evaluating mild analgesics. Journal of Neuroscience Methods 14(1): 69-76.

12. Amann R, Schuligoi R, Lanz I, Donnerer J (1995) Histamine induced edema in the rat paw - effect of capsaicin denervation and a Cgrp receptor antagonist. Eur J Pharmacol 279(2): 227-231.

13. Enoch Kumar Perimal, Muhammad Nadeem Akhtar, Azam Shah Mohamad, Mohd Hanief Khalid, Ong Hui Ming, et al. (2010) ZerumboneInduced Antinociception: Involvement of the L-Arginine- Nitric OxidecGMP -PKC-K', ATP Channel Pathways. Basic \& Clinical Pharmacology \& Toxicology 108: 155-162.

14. Ferrfindiz ML, Alcaraz MJ (1991) Anti-inflammatory activity and inhibition of arachidonic acid metabolism by flavonoids. Agents and Actions 32(3): 283-288.

15. Holzer P (1988) Local effector functions of capsaicin-sensitive sensory nerve endings: involvement of tachykinins, calcitonin gene-related peptide and other neuropeptides. Neuroscience 24(3): 739-768. 
16. Shibata M, Ohkubo T, Takahashi H, Inoki R (1989) Modified formalin test: characteristic biphasic pain response. Pain 38(3): 347-352.

17. Janscó G, Király E, Janscó Gábor (1977) A Pharmacologically induced selective degeneration of chemosensitive primary sensory neurones. Nature 270: 741-743.

18. Caterina MJ, Leffler A, Malmberg AB, Martin WJ, Trafton J, et al. (2000) Impaired nociception and pain sensation in mice lacking the capsaicin receptor. Science 288(5464): 306-313.

19. Hill SJ, Ganellin CR, Timmerman H, Schwartz JC, Shankley NP, et al. (1997) International Union of Pharmacology. XIII. Classification of histamine receptors. Pharmacol Rev 49(3): 253-278.

20. Anne Collins Abrams, Sandra Smith Pennington RN, Carol Barnett Lammon RN (2006) Antihistamines and Allergic Disorders (48). The Clinical Drug Therapy Rationales for Nursing Practice (Field Guide Series).

21. Pierce PA, Xie GX, Levine JD, Peroutka SJ (1996) 5-Hydroxytryptamine receptor subtype messenger RNAs in rat peripheral sensory and

ISSN: 2574-1241

DOI: 10.26717/BJSTR.2019.23.003858

Nasser Belboukhari. Biomed J Sci \& Tech Res

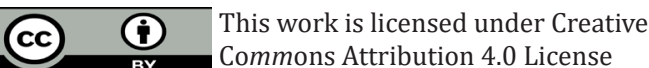

Submission Link: https://biomedres.us/submit-manuscript.php sympathetic ganglia: a polymerase chain reaction study. Neuroscience 70(2): 553-559.

22. Nicholson R, Small J, Dixon AK , Spanswick D, Lee K, et al. (2003) Serotonin receptor mRNA expression in rat dorsal root ganglion neurons. Neurosci Lett 337(3): 119-122.

23. Moalem G, Grafe P, Tracey DJ (2005) Chemical mediators enhance the excitability of unmyelinated sensory axons in normal and injured peripheral nerve of the rat. Neuroscience 134(4): 1399-1411.

24. Philip J Cow (1998) Adults: Clinical Formulation \& Treatment in Comprehensive. Clinical Psychology 6: 135-161.

25. Gholijani N, Gharagozloo M, Farjadian S, Amirghofran Z (2016) Modulatory effects of thymol and carvacrol on inflammatory transcription factors in lipopolysaccharide-treated macrophages. J Immunotoxico 13(2): 157-164.

26. Chien TC, Lo SF, Ho CL (2014) Chemical composition and antiinflammatory activity of Chamaecyparis obtusa $f$. formosana wood essential oil from Taiwan. Nat Prod Commun 9(5): 723-726. 